\title{
2. The Neglected Problem of Democratic Leadership
}

\author{
John Kane and Haig Patapan
}

\section{Introduction}

Australia is usually regarded as one of the most democratic of countries. One of the signs of this is said to be the permanent, seemingly entrenched scepticism of Australians about politics in general and especially about the politicians they elect to lead them. Polls regularly show a curious disjunction between approval ratings for the political system itself, which are always high, and those for the politicians who inhabit it, which are invariably much lower. More than sceptical, Australians are often downright cynical about the motives and actions of their political leaders, even when they support the leader's party. If hope is occasionally vested in new leadership it is always subject to the lingering fear, or even expectation, that hope will inevitably be betrayed, sooner rather than later.

It is a mistake to think, however, that this is a peculiarly Australian phenomenon rather than a general feature of democratic government. The core animating principle of democracy is popular sovereignty, the idea that the people should rule. Yet democratic leaders inevitably exercise far more authority than ordinary citizens. This creates a permanent tension between the democratic leader and the sovereign people that engenders the kind of suspicion of leadership noted above. The fact that this tension is, in principle, irresolvable (as we would claim) gives democratic leadership its special character, explaining both its remarkable strengths and acknowledged weaknesses. Democratic leadership is, indeed, uniquely challenging because it must be most carefully exercised under conditions of peculiar constraint and constant distrust.

This is an important subject inadequately addressed in the scholarship. Indeed, the problem of democratic leadership constitutes a permanent blind spot for most modern students of democracy. Whole volumes dedicated to an appraisal of the state of democratic theory contain hardly a reference to the question (Held 1993; 1996; Shapiro and Hacker-Cordón 1999; Carter and Stokes 2002). Nor does it appear as a major (or even minor) theme in university teaching, at least according to a 2003 survey of American classes by Ronald Terchek (2003). Despite the modern flood of literature on leadership generally, the problem of specifically democratic leadership seldom appears. We argue that this strange silence is in fact symptomatic of the ambiguous place that leadership occupies in a democracy, 
being both essential to democratic government yet finding no secure justification within a theory resting on the concept of popular sovereignty.

With regard to this central ambiguity we may discern two fundamentally opposed tendencies. So-called elitist theorists resolve it in favour of leadership at the expense of popular sovereignty. The most famous formulation of their position asserts that oligarchic rule is an 'iron law' of politics. More democratically-inclined scholars, on the other hand, have reacted to the elitist challenge by trying to resolve the tension in favour of popular sovereignty. They do not so much solve the problem of democratic leadership as pass it over in embarrassed silence, typically pursuing more ideally 'democratic' political forms that envisage wider or even universal citizen participation in political processes and decisions. These strategies implicitly eschew the need for leadership altogether. A few scholars accept the importance of democratic leadership while recognising the tension between leadership and popular sovereignty, but they cannot resist the temptation to resolve it by prescriptively defining a type of leader who might guarantee good leadership while not betraying the promise of popular sovereignty. ${ }^{\text {l }}$

The present scholarship on democratic leadership is deficient precisely because it is unwilling to contemplate the possibility that the tension between leadership and popular sovereignty is incapable of resolution. We claim that this is not a political problem to be overcome but rather a theoretically invaluable starting point for understanding both the unique authority of democratic leaders and the perennial challenges they face. We have no space to pursue that argument here, but will clear the way for such a study by addressing the curious poverty of contemporary theoretical studies of democratic leadership.

\section{The question ignored}

The absence of scholarship on democratic leadership seems puzzling at a time when centres for leadership mushroom across the globe and when books on leadership pour off the presses at an alarming rate. There is hardly a problem or conflict anywhere in the world whose cause is not attributed, at least in part, to poor leadership, and for which the proposed solution is not more or better leadership. In the everyday discourse of liberal democracies, the quality of political leadership, whether to be lamented or celebrated, is a perennial theme.

Much of the extant literature on leadership is sociological, psychological, or organisational. Derivative from this, and highly repetitive, is a vast volume of material aimed at corporate CEOs looking for the secrets of business success. There is also a lesser quantity of material on specifically political leadership, much of it growing out of Weber's threefold division of authority into the customary, the charismatic, and the legal-rational. In this contemporary field, James McGregor Burns $(1978$; 2003) remains a dominant figure (as he does, 
indeed, in the business canon). But as the subject of political leadership encompasses figures like Napoleon, Stalin and Hitler, this work does not necessarily tell us much about the specific nature and distinctive challenges of democratic leadership. An even smaller literature on leadership in liberal democracies is mostly comparative and empirical, being either concerned with the institutional constraints and opportunities facing leaders in different democratic countries, or closely focused on particular historical figures (Mughan and Patterson 1988; Jones 1989; Elgie 1995).

What is lacking is a body of theory that provides, or attempts to provide, a reasoned explanation of, and foundation for, the role of leadership in representative democracies. This is despite the fact that the problem of democratic leadership is a prominent, if often only implicit, theme in historical and analytical studies of particular democratic leaders, both prime ministers and presidents. ${ }^{2}$ It may be significant that such work, though voluminous, is somewhat ghettoised by hard-nosed political scientists who regard leadership as little more than an epiphenomenon overlying 'real' causal processes understood, usually, in economic, social-structural or institutional terms. Such positivistic attitudes, which regard leadership as not warranting serious theoretical investigation, might be thought, on their own, to explain the gap in democratic theory. But political science's principal disdain has not been for democratic theory as such (which it scarcely acknowledges), but rather for what it regards as the 'soft' empiricism of existing leadership studies. Though it is true that political and democratic theory in modern times has suffered from the cultural dominance of the natural sciences (see below), 'scientific' prejudice alone cannot explain the lack of theoretical reflection on democratic leadership. The real answer lies interestingly deeper.

We argue that this lack is no accident but itself tells us a lot about the problem. Democratic leadership is a blind spot for most democratic theorists and students of leadership because democrats have difficulty in articulating a proper democratic role for leadership. Democrats who feel the need for a leader must reconcile this with the belief that none among equals has any innate or inherent right to rule over others. On the one hand, democracy seems to require good leadership if it is to function effectively; on the other, the very idea of leadership seems to conflict with democracy's egalitarian ethos. The more strongly democratic leaders lead, the less democratic they appear; the more they act like good democrats, the less like true leaders they seem. Confronted with this dilemma, the general tendency among scholars has therefore been to accept the need for leadership in practice while overlooking it in theory.

\section{The elitist flight from democracy}

There is, however, another powerful reason why scholars ignore the problem of democratic leadership. The association of leadership with elites, and elites 
with hierarchy, subordination and exclusion, goes a long way toward explaining the failure of democratic theory to address clearly the issue of democratic leadership. Elite theorists of the early twentieth century powerfully reinforced the suspicions of egalitarian democrats by confirming the essential relationship between leaders and elites. They effectively resolved the core ambiguity between leadership and popular sovereignty by exalting the former over the latter.

William James (1912: 318) claimed that the problem of democracy could be reduced to a single question: What kinds of men are going to be charged with the responsibility of giving the cue to the masses? In more sociological mode, others argued that elite formation and rule by elites was unavoidable in the modern world (Pareto 1935; Mosca 1939). Elite control of decision-making and coordination was simply a functional necessity in complex organisations, including the political organisation of liberal democracy. Because these claims were couched in hard sociological terms, stamped with the authority of scientific fact, their impact on democratic theorists was profound. Indeed, democratic theory since 1915 can be interpreted as a variety of attempts to affirm, modify or transcend what Robert Michels (1962) then described as the iron law of oligarchy'.

Elite theorists who resolved the tension between leadership and popular sovereignty in favour of leadership, by affirming elitism, were compelled to redefine the classical conception of democracy as the rule of all (or at least of the many). Harold Lasswell claimed that a democracy could rightly express itself through just a few leaders provided those leaders remained accountable (Lasswell 1950: 201; Lasswell et al. 1952: 7). Joseph Schumpeter famously argued a revised version of representative democracy as free competition between elites for the people's vote. This was not government by the people, but government approved by the people (Schumpeter 1961: 246). In fact the less involvement people had with political processes and decision-making between elections the better. Liberty was preserved in such a democracy not by citizen engagement but by the balancing of autonomous, countervailing elites, none of which could concentrate all power in their hands (see also, Aron 1968; 1978; Kornhauser 1959; Etzioni-Halevy 1993). Openness to talent allowed the 'free circulation of elites' which was, according to Giovanni Sartori (1962: 85), what distinguished the democratic elite principle from others.

Sartori, however, even more emphatically than Schumpeter, confirmed the leadership function of the 'superior' few. Democracies, he said, have to reckon with 'minorities who count for much and lead, and with majorities who do not count for much and follow' (1962: 98). But on Sartori's view the main task of democratic leaders was to defend democracy against itself, or rather against its own excessive tendencies toward the 'perfectionistic' pursuit of the democratic ideal on the one hand, and demagogic mass manipulation on the other. Leaders 
were the necessary stabilisers of a potentially unstable system. 'And this is why adequate leadership is vital to democracy,' he declared, adding that eminent leadership was most necessary when pressure from below was (1962: 119). It was a sentiment echoed by the American V. O. Key Jr. (1961), who argued that only an elite leadership could shoulder the responsibility of forestalling a natural propensity in democracy toward indecision, decay and disaster.

As this revised model of democracy implied a deep distrust of the volatile masses and the need to exclude them from everyday political processes, it was little wonder that some democratic theorists felt extremely uncomfortable with it. Nor was it surprising, given that elite theory so closely identified itself with leadership, that theorists seeking to evade its logic should virtually ignore the question of democratic leadership. Pluralists, for example, sought to neutralise rather than to redefine the role of democratic leadership by arguing that power and influence were less concentrated in modern democracies than elite theory suggested. Power, they said, was dispersed among a plurality of civil groups to which individuals belonged, these groups competing for influence upon a 'neutral', interest-mediating state (Galbraith 1952; Dahl 1958; Truman 1971). Democracy might not work individualistically, as classical theory held, but it worked nevertheless. Fragmentation disallowed 'strong' versions of elite leadership and reinstated the possibility that democracy remained, at least in this reinterpreted sense, 'government by the people'.

The iron grip of elitism was not, however, so easily slipped. Critics of pluralism objected that modern democracy was neither as benign nor accessible as Dahl suggested. They confirmed the elitist picture if only to deplore it, often reinterpreting it in quasi-Marxist economic terms. They argued that the will of the people was systematically subverted by the hidden hand of a structural economic-political elite that established political agendas by suppressing issues threatening to its power (Bachrach and Baratz 1962; 1963; 1970; Crenson 1971; Lukes 1974; Gaventa 1980). Even Dahl, later in his career, accepted that tiny minorities in America made the key economic, political and social decisions, and that it could hardly be otherwise in a large political system (Dahl and Lindblom 1976). He would contend at last that the economic power of business elites contradicted the very essence of democracy (Dahl 1982; 1985).

These Marxist-influenced theories might seem to have implied the need for revolutionary change in both economic arrangements and people's consciousness, but most democratic theorists remained fundamentally liberal in temper. They were disinclined to hope, given the example of twentieth century revolutions, that socialistic egalitarianism would result in a truly democratic control of politics. In communist countries the nexus between leadership and elite had been not only reproduced but brutally reaffirmed, with the added disadvantage that accountability now travelled in a new, undemocratic direction - the people 
were accountable to the Leninist vanguard party and the party was accountable to no one. Yet anti-elitists' own prescriptive remedies tended to be weak. Peter Bachrach wrote a book stringently criticising democratic elitist theory which nevertheless asserted that ' $[\mathrm{t}]$ he main thrust of the elitist argument is incontestable' (Bachrach 1967: 95). More contemporary theorists simply take this as a truism, using it as their starting point for their analyses of elite formation and change (Higley and Burton 2006).

What was notable about Bachrach's critique, however, was its defence of the classical view that democracy implied citizen participation in all aspects of public affairs as 'an essential means to the full development of individual capacities' (1967: 4). Dahl (1985) took up the same theme, arguing that 'real' democracy required that public participation be greatly enhanced in all spheres of life, implying an equalisation of the ownership and control of both economic production and the political agenda (McLennan 1989). This turn of argument was indicative of nearly all work on democratic theory in the latter part of the twentieth century whether it emphasised the economic dimension or not. Democrats sought in diverse ways for theoretical avenues that led away from elitism and toward what they hoped might be 'real' or 'strong' democracy.

\section{The democratic flight from leadership}

This flight from elitism in fact represented the modern theorists' resolution of the tension between leadership and popular sovereignty. Unable to refute the elite thesis, they hoped that strengthening democracy, through the widest possible participation by the totality of citizens in civil and political activity, would somehow disempower permanent elites. There was also the unstated belief that a reinvigorated democracy might solve the problem of democratic leadership by allowing all to lead. But because the mental association of leadership with elites was strong, the natural tendency was to avoid any explicit treatment of the question of leadership. The consequence of these theorists' preference for popular sovereignty over leadership was therefore a complete neglect of the problem of democratic leadership.

Attempts to redefine a 'truer' democracy took a number of forms. 'Inclusive democrats,' for example, were concerned to realise a democratic egalitarian ideal they claimed had been subverted in liberal democracies by the exclusion of certain disadvantaged groups (Young 1989; 1990; 1997; Taylor 1992; Honneth 1995). Iris Young (1997: 370) proposed special representation rights to 'women, blacks, native Americans, Chicanos, Puerto Ricans ... Asian Americans, gay men. Lesbians, working-class people, poor people, old people, and mentally and physically disabled people' - in other words to a majority of the US population excluding, it seemed, only white, propertied males presumed still to be in control of the means of power and dominance (Young 1989: 261; see Kane 2002: 119). Other theorists were guided by an ideal of direct democracy (Pateman 1970; 
Held 1996). Benjamin Barber argued for a ground-up development of direct democratic procedures starting from the local and progressing all the way to the national (Barber 1984). Associational democrats, by contrast, believed that the solution to the ills of the modern world lay in the devolution of economic and political power to various voluntary civil associations under the direct democratic control of their members (Hain 1983; Hirst 1994; Cohen and Rogers 1995; Giddens 1998).

Post-structural or 'post-modern' writing, by contrast, had rather unclear political theory implications, perhaps because of a radical tendency to decentre or reduce the citizen-self to some structural or discursive effect (Foucault 1983: 211-12; Lyotard 1977: 47; 1985: 36; Rorty 1989: 37-8). But when post-moderns did explicitly address the issue of democracy, it was typically to stress the need for radicalisation, meaning movement toward more direct and participative forms (Laclau and Mouffe 1985). For Jacques Derrida, this democratic impulse was tragically unfulfillable because of an inherent tendency to corruption in egalitarian institutions, a virtual acceptance of Michel's iron law, though Derrida's romantic prescription was that we nevertheless perpetually orient ourselves toward the unrealisable ideal (Derrida 1994). The so-called deliberative democrats, meanwhile, looked to establishing or reforming institutional and communicative means by which all citizens might play a part in political decision-making (Dryzek 1990; Habermas 1996; Guttman and Thompson 1996; Benhabib 1996; Cohen 1998; cf. Uhr 1998). The common commitment of theorists in this field was 'to the notion that political decisions are better made through deliberation than money or power, as well as to the ideal that participation in deliberative judgements should be as equal and widespread as possible' (Warren 2002: 196).

In all these non-elite democratic theories there was an assumption that greater democratisation could be recognised by how far decision-making was removed from the hands of an elite and distributed among 'the people'. The general tendency was clear. The theoretical landscape had become dominated by attempts to escape or overcome the problem of democratic leadership by annihilating the need for it.

\section{Conclusion}

Our intention here has been to clear the conceptual ground for a deeper study of democratic leadership as it actually exists. ${ }^{3}$ Our orientation in approaching this study is to resist the common temptation to resolve the tension between leadership and popular sovereignty and to argue that it is in fact perennial and irresolvable. Not only that, we argue that this irresolvability is a good thing, democratically speaking. It is an essential motive force that helps to drive and sustain the highly flexible and dynamic system of government we call democracy. 
We have argued here that one of the most striking consequences of the democratic leadership tension has been the relative neglect of the problem of democratic leadership as it is, and as it must be, practised in the real world. We believe that we will not properly understand the distinctive advantages and opportunities - nor the distinctive challenges and constraints - of democratic leaders if we continue to disparage them through an act of comprehensive, even if unconscious, oversight. Theory must engage with the in-built and unavoidable mistrust of leadership in democracies if it is to appreciate the perpetual question of legitimacy that hangs over the head of every democratic leader, and which he or she must continually negotiate. It is our contention that this perpetual demand to legitimise leadership is, in fact, the way that the principle of popular sovereignty manifests itself and is continuously realised in democratic government.

\section{References}

Aron, R., 1968, Progress and Disillusion, London: Pall Mall.

Aron, R., 1978, Politics and History, New York: Free Press.

Bachrach, P. S., 1967, The Theory of Democratic Elitism, Boston: Little, Brown.

Bachrach, P. S. and M. S. Baratz, 1962, 'Two faces of power', American Political Science Review, 56, pp. 1947-52.

Bachrach, P. S. and M. S. Baratz, 1963, 'Decisions and non-decisions: an analytic framework', American Political Science Review, 57, pp. 641-51.

Bachrach, P. S. and M. S. Baratz, 1970, Power and Poverty, Theory and Practice, New York: Oxford University Press.

Barber, B., 1984, Strong Democracy, Berkeley: University of California Press.

Burns, J. MacGregor, 1978, Leadership, New York: Harper Colophon.

Burns, J. MacGregor, 2003, Transforming Leadership, New York: Atlantic Monthly Press.

Carter, A. and G. Stokes (eds), 2002, Democratic Theory Today, Cambridge: Polity Press.

Cohen, J., 1989, 'The Economic Basis of Deliberative Democracy', Social Philosophy and Policy, 6:2, pp. 25-50.

Cohen, J. and J. Rogers, 1993, 'Associations and Democracy', Social Philosophy and Policy, 10, pp. 282-312.

Crenson, M. A., 1971, The Unpolitics of Air Pollution: A Study of Non-decision Making in the Cities, Maryland: Johns Hopkins University Press.

Cronin, Thomas E. and Michael A. Genovese, 1998, The Paradoxes of the American Presidency, New York: Oxford University Press. 
Dahl, R. A., 1961, Who Governs? Democracy and Power in an American City, New Haven: Yale University Press.

Dahl, R. A., 1982, Dilemmas of Pluralist Democracy, New Haven: Yale University Press.

Dahl, R. A., 1985, A Preface to Economic Democracy, Cambridge: Polity Press.

Dahl, R. A. and C. E. Lindblom, 1976, Politics, Economics and Welfare, Chicago: University of Chicago Press.

Derrida, J., 1994, Spectres of Marx: The State of the Debt, the Work of Mourning, and the New International, trans. P. Kamuf. New York: Routledge.

Dryzek, John S., 1990, Discursive Democracy: Politics, Policy, and Political Science, New York: Cambridge University Press.

Edwards, G., J. H. Kessel and B. A. Rockman (eds), 1993, Researching the Presidency: Vital Questions, New Approaches, Pittsburgh: University of Pittsburgh Press.

Elgie, R., 1995, Political Leadership in Liberal Democracies, London: Macmillan.

Elster, J. (ed.), 1998, Deliberative Democracy, Cambridge: Cambridge University Press.

Etzioni-Halevy, E., 1993, The Elite Connection: Problems and Potential of Western Democracy, Cambridge: Polity Press

Fearon, J. D., 1998, 'Deliberation as Discussion', in J. Elster (ed.), Deliberative Democracy, pp. 44-68.

Foley, M., 2000, The British Presidency: Tony Blair and the Politics of Public Leadership, Manchester: Manchester University Press.

Galbraith, J. K., 1952, American Capitalism, Boston: Houghton Mifflin.

Gardner, John W., 1990, On Leadership, New York: Free Press.

Gaventa, J., 1980, Power and Powerlessness: Quiescence and Rebellion in the Appalachian Valley, Oxford: Clarendon Press.

Giddens, A., 1998, The Third Way: The Renewal of Social Democracy, Malden, MA.: Blackwell.

Greenstein, F. I. (ed.), 1988, Leadership in the Modern Presidency, Harvard: Harvard University Press.

Guttman, A., 1993, 'The Challenge of Multiculturalism in Political Ethics', Philosophy and Public Affairs, 22, pp. 171-206.

Hain, P., 1983, The Democratic Alternative: A Socialist Response to Britain's Crisis, Harmondsworth: Penguin. 
Hargrove, E. C., 1998, The President as Leader: Appealing to the Better Angels of Our Nature, Lawrence: University of Kansas Press.

Heffernan, Richard, 2005, Exploring (and Explaining) the British Prime Minister. British Journal of Politics and International Relations, vol. 7, pp. 605-20.

Held, D. (ed.), 1993, Prospects for Democracy, Cambridge: Polity Press.

Held, D., 1996, Models of Democracy, Cambridge: Polity Press.

Hennessy, P., 2000, The Prime Minister: The Office and its Holders Since 1945, London: Allen Lane.

Higley, John and Michael Burton, 2006, Elite Foundations of Liberal Democracy, Lanham, MD: Rowman and Littlefield.

Hirst, P., 1994, Associative Democracy: New Forms of Economic and Social Governance, Cambridge: Polity Press.

Honneth, A., 1995, The Struggle for Recognition: The Moral Grammar of Social Conflicts, trans. Joel Anderson. Cambridge, MA.: Polity Press.

James, W., 1897, The Will to Believe, New York: Longmans, Green and Co.

James, W., 1912, Memories and Studies, New York: Longmans, Green and Co.

Jones, B. D., 1989, Leadership and Politics: New Perspectives in Political Science. Kansas: University Press of Kansas.

Kane, J., 2002, 'Democracy and Group Rights', in A. Carter and G. Stokes (eds), Democratic Theory Today, pp. 97-120.

Kane, John, Patapan, Haig and Benjamin Wong (eds), 2008, Dissident Democrats: The Challenge of Democratic Leadership in Asia, New York: Palgrave Macmillan.

Key Jr., V. O., 1961, Public Opinion and American Democracy, New York: Knopf.

Kornhauser, A. W., 1959, Problems of Power in American Democracy, Detroit: Wayne State University Press.

Laclau, E. and C. Mouffe, 1985, Hegemony and Socialist Strategy: Towards a Radical Democratic Politics, New York: Verso.

Lasswell, H. D, 1950, Power and Society: A Framework for Political Inquiry, New Haven: Yale University Press.

Lasswell, H. D., D. Lerner and C. E. Rothwell, 1952, The Comparative Study of Elites: An Introduction and Bibliography, Stanford: Stanford University Press.

Lijphart, A. (ed.), 1992, Parliamentary Versus Presidential Government, Oxford: Oxford University Press. 
Lord, Carnes, 2003, The Modern Prince: What Leaders Need to Know Now, Yale: Yale University Press.

Lukes, S., 1974, Power: A Radical View. London: Macmillan.

Lyotard, J. F., 1997 [1976], The Postmodern Condition: A Report on Knowledge [including Appendix, 'What is Postmodernism?'] trans. G. Bennington and B. Massumi. Minneapolis: University of Minneapolis Press.

Lyotard, J. F., 1985, Just Gaming, trans. W. Godzich. Manchester: Manchester University Press.

Mackintosh, John P., 1977, The British Cabinet, $3^{\text {rd }}$ edition, London: Stevens and Sons.

McLennan, G., 1989, Marxism, Pluralism and Beyond, Cambridge: Polity Press.

Miroff, Bruce, 2000, Icons of Democracy: American Leaders as Heroes, Aristocrats, Dissenters, and Democrats, Kansas: University Press of Kansas.

Mosca, G., 1939, The Ruling Class, trans. H.D. Kahn. New York: McGraw-Hill.

Mughan, A. and S. C. Patterson (eds), 1988, Political Leadership in Democratic Societies, Chicago: Nelson-Hall.

Neustadt, R. E., 1990, Presidential Power and the Modern Presidents, New York: Free Press.

Nevins, A., 1962, The Statesmanship of the Civil War, New York: Macmillan.

Novak, M., 1982, 'The Communitarian Individual in America', The Public Interest, 68, pp. 3-20.

Pareto, V., 1935, Mind and Society, trans. A. Livingston. New York: McGraw-Hill.

Pateman, C., 1970, Participation and Democratic Theory, Cambridge: Cambridge University Press.

Pennock, J., 1979, Democratic Political Theory, Princeton: Princeton University Press.

Putnam, R. D., 1993., Making Democracy Work: Civic Traditions in Modern Italy, Princeton: Princeton University Press.

Rawls, J., 1993, Political Liberalism, New York: Columbia University Press.

Rorty, R., 1989, Contingency, Irony and Solidarity, Cambridge: Cambridge University Press.

Ruscio, Kenneth Patrick, 2004, The Leadership Dilemma in Modern Democracy, Cheltenham, UK; Northampton, MA: Edward Elgar.

Sartori, G., 1962, Democratic Theory. Based on the author's translation of Democrazia e definizione, Detroit: Wayne State University Press. 
Schumpeter, J., 1961 [originally 1942], Capitalism, Socialism and Democracy, London: Allen \& Unwin.

Shapiro, I. and C. Hacker-Cordón (eds), 1999, Democracy's Edges and Democracy's Value (companion volumes), Cambridge: Cambridge University Press.

Shapiro, I., 1996, Democracy's Place, Ithaca, NY: Cornell University Press.

Shogan, R., 1998, The Double Edged Sword: How Character Makes and Ruins Presidents, Boulder, CO.: Westview Press.

Skowronek, S., 1997, The Politics Presidents Make: Leadership from John Adams to Bill Clinton, Cambridge, MA: Belknap.

Taylor, C., 1992, Multiculturalism and the Politics of Recognition, Princeton: Princeton University Press.

Terchek, R. J., 2003, 'Teaching Democracy: A Survey of Courses in Democratic Theory', Perspectives on Politics (American Political Science Association), 1:1, pp. 147-55.

Truman, D., 1971, The Governmental Process, $2^{\text {nd }}$ edition, New York: Knopf.

Uhr, John, 1998, Deliberative Democracy in Australia, Cambridge: Cambridge University Press.

Warren, M., 2002, 'Deliberative Democracy', in Carter and Stokes (eds), Democratic Theory Today, pp. 173-202.

Woodhouse, D., 1994, Ministers and Parliament: Accountability in Theory and Practice, Oxford: Oxford University Press.

Young, I. M., 1989, 'Polity and Group Difference: A Critique of the Ideal of Universal Citizenship', Ethics 99:2 [Reprinted in S. Gershon (ed.), 1998, The Citizenship Debates: A Reader, Minnesota: University of Minnesota Press].

Young, I. M., 1997, 'Deferring Group Representation', in I. Shapiro and W. Kymlicka (eds), NOMOS XXXIX: Ethnicity and Group Rights, New York: New York University Press.

\section{ENDNOTES}

${ }^{1}$ We have not space to examine these in detail here, but see especially Pennock (1979); Miroff (2000); Lord (2003); and Ruscio (2004).

2 On prime ministers consider, for example, Lijphart (1992); Woodhouse (1994); Mackintosh (1977); Hennessy (2000); and the recent scholarship on the 'presidentialisation' of the office of prime minister, for example, Foley (2000); Hargrove (2001). On US presidents see Neustadt (1990, 1997); Greenstein (1988); Edwards et al. (1993); Skowronek (1997); Hargrove (1998); Shogan (1998).

3 For the usefulness of the concept of 'democratic leadership' in understanding the nature of dissent and democratic transitions in Asia see Kane et al. 2008. 